\title{
RAZVOJ ODNOSA STAREJŠIH ODRASLIH Rajka Bračn DO SODOBNE LIKOVNE UMETNOSTI

\section{POVZETEK}

$V$ prispevku je predstavljena kvalitativna empirična raziskava o odnosu starejših odraslih do sodobne likovne umetnosti, ki je bila opravljena z analizo odzivov na razstavo del umetnika Jožeta Baršija v Muzeju sodobne umetnosti v Ljubljani spomladi 2013. Izpeljani sta bili dve fokusni skupini - pred ogledom razstave in po njem, ko so starejši prišli $v$ neposreden stik z umetnikom in njegovimi deli. Rezultati kažejo na odnos starejših odraslih do sodobne (slovenske) likovne umetnosti in potencial ustrezno zasnovanega izobraževanja pri razvoju zmožnosti za doživljanje in estetsko presojanje likovnih del. Analiza, ki je temeljila predvsem na teoriji kulturnega kapitala in na s tem povezanem konceptu estetske kompetence, teoriji izobraževalnih potreb starejših in teoriji likovne umetnosti, je pokazala na pomen družbenega in kulturnega konteksta. Avtorica raziskave ugotavlja, da mora izobraževanje starejših na področju sodobne likovne umetnosti ponuditi starejšim odraslim več raznolikih možnosti, pri čemer imajo muzeji kot družbene institucije posebno vlogo. Če z izobraževanjem zgolj sledimo že razvitim potrebam (osebnim zanimanjem) starejših odraslih, jih v doživljanje sodobne likovne umetnosti ne privabimo.

Ključne besede: umetnostni muzej, sodobna likovna umetnost, odnos do umetnosti, starejši odrasli, družbene potrebe

\section{DEVELOPMENT OF OLDER ADULTS - THEIR ATTITUDE TOWARDS CONTEMPORARY ART - ABSTRACT}

The paper presents a qualitative empirical research on older adults' attitude towards contemporary visual art, bringing an analysis of their responses to the exhibition of the artist Jože Barši in The Museum of Contemporary Art, Ljubljana, in spring 2013. Two groups were focused on and examined before and after visiting the exhibition, where the older adults had direct contact with the artist and his works. The results show the attitude of older adults towards contemporary (Slovene) visual art and the potential of proper education for the development of their aesthetic competences. The analysis was based on theoretical frameworks, related to cultural capital and aesthetic competence, the educational needs of older adults and the theory of art. The analysis demonstrated the importance of the social and cultural context. The author suggests that there should be more possibilities for art education of older adults, in which museums as social institutions should have a special role. If in the education for older adults we follow only their personal interests, we will not manage to make them experience contemporary visual art.

Keywords: art museum, contemporary visual art, attitude towards art, older adults, social needs

UDK: $374.7: 73$

\section{UVOD}

$\mathrm{V}$ prispevku predstavljam odnos starejših odraslih do sodobne (slovenske) likovne umetnosti ter potencial ustrezno zasnovanega izobraževanja pri njegovem razvoju in oblikovanju. V kvalitativni raziskavi so sodelovali posamezni člani dveh študijskih krožkov za umetnostno zgodovino na ljubljanski univerzi za tretje življenjsko obdobje. Po podatkih univerze je zgodovina likovne umetnosti ena najbolj priljubljenih učnih vsebin v tretjem življenjskem obdobju pri nas (prim. Šterman, 2006). Če naj programi s področja likovne umetnosti učečim se (tudi starejšim) omogočajo, da razvijajo zmožnost doživljanja in razumevanja likovne umetnosti, bi pričakovali, da ti programi vključujejo tudi sodobno umetnost in razvijajo pri starejših odraslih ustvarjalen odnos tudi do sodobne likovne produkcije. 
V slovenskem prostoru raziskav o tej problematiki praktično nimamo. Likovna umetnost - s poudarkom na njenem razumevanju, avtentični prostor za to pa je v prvi vrsti umetnostni muzej - je kot področje učenja in poučevanja po celotni vertikali izobraževalnega sistema dokaj neraziskana. To velja tudi za izobraževanje starejših odraslih; andragoginja N. Ličen v svoji razpravi o izobraževanju odraslih med moderno in postmoderno večkrat omeni pomanjkanje empiričnih raziskav na tem področju (2006: 181, 182, 184). Namen pričujoče raziskave je prispevati k zapolnitvi te vrzeli.

Tudi če vzamemo pod drobnogled najnovejšo strategijo vzgoje in izobraževanja v Sloveniji (Bela knjiga, 2011), ugotovimo, da ta - predvsem v navedenih splošnih ciljih - pravzaprav zahteva merjenje učinkov na področju izobraževanja odraslih. Obravnavo sistemskih vprašanj, kot so udeležba, dostopnost, ponudba, organizacija in financiranje (gl. Čelebič idr., 2011), je torej treba dopolniti s kurikularnimi/programskimi, zlasti z vidika učnih ciljev, vsebin in metod. Ta prispevek v središče problema postavlja učinke skozi obravnavo doživljanja in razumevanja sodobne likovne umetnosti pri starejših odraslih.

V tujini raziskovalci izobraževalnemu potencialu likovne umetnosti v (pozni) odraslosti in procesom estetskega doživljanja namenjajo bistveno več pozornosti. Razvita je tudi raziskovalna metodologija. Raziskave večinoma potekajo v avtentičnih okoljih - v umetnostnih muzejih - in temeljijo na intervjujih (lahko v kombinaciji z opazovanjem). Najpogostejša tehnika pri individualnem intervjuju je izražanje misli, asociacij in občutkov, ki se obiskovalcu porajajo med ogledovanjem umetnin. Uporabljajo jo tako kognitivno kot konstruktivistično usmerjeni raziskovalci (npr. Dufresne-Tassé idr., 1998; Lachapelle, 1999; Hooper-Greenhill idr., 2001; Hoo-
per-Greenhill idr., 2001; Van Moer, 2007; Émond, 2010), omogoča pa proučevanje načinov ogledovanja umetniških del v muzejih, razlik med obiskovalci, vpliva predznanja na razumevanje umetnosti, vpliva muzejskega konteksta in podobno. S skupinskimi intervjuji ali fokusnimi skupinami pa je mogoče preverjati na stališčih in prepričanjih izoblikovano poznavanje umetnosti in muzejev.

Raziskovalci z Univerze v Newcastlu so pokazali na korelacijo med zmožnostjo razumevanja sodobne likovne umetnosti in oblikovanjem identitete pri starejših odraslih (Newman idr., 2012). Vse od 90. let 20. stoletja dalje poznamo eksperimentalne študije z različno estetsko izkušenimi odraslimi obiskovalci umetnostnih muzejev, ki dokazujejo, da se ljudje na umetniška dela odzivamo na svoj način ter da v doživetja vnašamo osebne izkušnje in na teh oblikovana - pozitivna ali negativna - prepričanja (za doživljanje sodobne likovne umetnosti npr. Van Moer, 2007). Raziskovalce zanima tudi, kako odrasli doživljamo likovno umetnost iz različnih obdobij. Zanimiv je primer kanadske raziskave med odraslimi nepoznavalci likovne umetnosti, ki je pokazal, da med zaznavanjem in sprejemanjem sodobne in starejše likovne umetnosti ni bistvenih razlik (Émond, 2010).

Z vidika izobraževanja in učenja starejših odraslih na področju likovne umetnosti se torej postavlja vrsta vprašanj. Ker je pri nas, kot že rečeno, to še neraziskano področje, sem se najprej osredotočila na proučevanje odnosa starejših odraslih do sodobne likovne umetnosti. Utemeljeno predvidevam, da se starejši v okviru izobraževalnih programov redko srečujejo s sodobno umetnostjo ali celo nikoli. ${ }^{1}$

Prispevek ima pet delov. Uvodnim opredelitvam namena in pomena raziskave sledi teoretični okvir, na podlagi katerega so bili 
pridobljeni in analizirani empirični podatki iz fokusnih skupin. Nato je prikazana metodologija empirične raziskave: predstavljena sta dva pogovora s starejšimi - pred ogledom razstave v Muzeju sodobne umetnosti in po njem -, ki ju je vodila avtorica, ter Baršijev koncept vodenega ogleda. Sledijo predstavitev in analiza rezultatov ter sklep.

\section{TEORETIČNI OKVIR}

Človekov odnos do likovne umetnosti ne nastane iz nič, temveč se izoblikuje kot skupek pridobljenih znanj in izkušenj. Na dejstvo, da ljudje nimamo posebnega estetskega čutila, temveč se moramo doživljanja umetniških del naučiti, je prvi opozoril Bourdieu s sodelavcem $\mathrm{v}$ raziskavi med obiskovalci izbranih evropskih umetnostnih in drugih muzejev v 60. letih 20. stoletja (Bourdieu, Darbel, 1969/1991). Njegova empirična študija, objavljena v knjigi L'amour de l'art: les musées d'art européens et leur public, ki je potekala med letoma 1964 in 1965 ter je zajela okoli 25 tisoč obiskovalcev umetnostnih muzejev v Franciji, pa tudi v Grčiji, Španiji, na Poljskem in Nizozemskem, je pokazala, da je estetski okus rezultat posameznikovega družbenoekonomskega položaja in vzgoje oziroma izobraževanja (tudi družinske socializacije). Ugotovil je, »da se obiskovanje muzejev poveča $\mathrm{z}$ višjo stopnjo izobrazbe in da je skoraj v celoti v domeni izobraženega razreda« (prav tam: 14). Kot ključni dejavnik tako pri pogostnosti obiskovanja muzejev kakor tudi pri strukturi estetske izkušnje se je pokazala izobrazba. (Bourdieujeva študija je opozorila na muzej kot dejavnik družbene reprodukcije.) Obiskovalci iz nižjega sloja in z manj znanja o umetnosti so raje obiskovali muzeje, kjer niso bile samo slike, ampak tudi zgodovinski in etnografski predmeti, v muzeju so iskali dodatne informacije o eksponatih (brali napise, upora- bljali vodnike), o umetniških delih niso imeli kakšnega posebej izdelanega mnenja (obisk so opisali z izjavami kot: »Vse je zelo lepo.«) in niso obvladali ustrezne terminologije, da bi se o umetninah poučeno izražali, jih vrednotili. Pripadniki višjega razreda, ki so, kot že rečeno, v muzejih prevladovali, so imeli izdelan »okus«; najraje so si ogledovali slike in kipe (prednost so dali estetski in ne uporabni vrednosti predmeta), zanimala jih je klasična umetnost ali takratna avantgarda, pogosto so tudi sami doma imeli umetniška dela.

V kolikšni meri sporočilnost umetniškega dela razumemo, je torej pretežno odvisno od našega predhodnega znanja, izkušenj in s tem povezanih zanimanj - na kratko, od kulturnega kapitala. Bourdieujeva teorija kulturnega kapitala nam pomaga razumeti vpliv šolanja, socializacijskih izkušenj in interakcij v družini na človekovo vedenje oziroma habitus. V skladu s to teorijo se muzejski obiskovalci različno zanimajo za muzeje in $\mathrm{v}$ njih različno dojemajo artefakte, saj so za razumevanje v muzejih hranjene dediščine različno kompetentni. Pojem kompetenca, ki ga uvede Bourdieu, opozarja na kompleksnost in uporabnost znanja, ki ni samoumevno in enostavno, temveč stvar vzgoje, saj estetsko doživljanje predvideva poznavanje umetniškega oziroma kulturnega koda - ponotranjenje estetskih pravil, odvisnih od zgodovine in družbe (Bourdieu, 1993: 215-237). Srečanje z umetnino ni »ljubezen na prvi pogled«, pravi Bourdieu (1979/2010: 3). Človek do estetskega užitka pride »z navado in vajo« (Bourdieu, Darbel, 1969/1991: 109), pri čemer je kultiviranje posameznika v domeni šole, pomembno obliko vzgoje pa je Bourdieu, kot rečeno, videl tudi v družini.

Pri izbraževanju starejših odraslih poleg kompetenc oziroma zmožnosti govorimo tudi o potrebah po učenju (npr. Ličen, 2006) oziroma motivaciji (npr. Findeisen idr., 2012: 48-70) za 
učenje. Gre za vprašanje, »kaj starejše motivira za učenje in izobraževanje « (prav tam: 49), pri čemer namen ni samo sledenje njihovim potrebam, ampak tudi njihovo ustvarjanje: »Če tisti, ki naj se učijo, niso dovolj motivirani, je potrebno nanje vplivati, jih tudi usmerjati k doseganju ciljev, da bi se obnašali tako, kot se zdi potrebno, ali tako, kot si to mi želimo.« (Prav tam.) Na to vplivanje je mogoče pogledati tudi s stališča vzgoje kot take. M. Peček Čuk in I. Lesar (2009), denimo, vzgojo opredeljujeta kot namerno, zavestno in načrtno dejavnost, ki pomeni sistematično vplivanje na vzgajanca in prinaša želene rezultate.

Glede na koncept kompetence in koncept potrebe ter motivacije lahko ugotovimo, da ni namen izobraževanja le sledenje osebnim zanimanjem, ampak tudi zadovoljevanje družbenih potreb. Zastavlja se vprašanje, ali nimajo morda na vzgojnem področju likovne umetnosti - še posebej, ko gre za razumevanje oziroma sprejemanje sodobne likovne produkcije, ki je izrazito družbeno kritična - družbene potrebe oziroma družbeni namen izobraževanja celo večji pomen od individualnega. (Govorim o slovenskem kulturnem kontekstu: postsocializmu, demokratizaciji, vključenosti v družbo.) Pomembno je namreč ustvarjanje potreb ali z drugimi besedami razvijanje motivacije za spoznavanje sodobne umetnosti; starejši sami po sebi razstav sodobne likovne umetnosti sploh ne obiskujejo, ker nimajo potrebe po tem - sodobna likovna umetnost jih »ne zanima«. To verjetno pomeni izgubo možnosti za spoznavanje družbenega prek umetnosti.

Likovna umetnost je namreč družbena praksa. Prenaša oziroma sporoča namene, vrednote, prepričanja, ideje, politična in druga sporočila ali čustvena stanja osebe, ljudi ali družbe, ki jo je sproducirala. Ume- tnost vpliva na naše predstave o realnosti in prepričanja o tem, kaj je lepo, resnično, pravično, vredno itd. Zato ima umetnost veliko vzgojno moč (prim. Carroll, 2003).

Maslow ni brez razloga med višje potrebe uvrstil potrebe po doživljanju lepega. Neposredno je to potrebo mogoče povezati $\mathrm{z}$ doživljanjem likovne umetnosti, na kar opozori tudi D. Findeisen. Seveda pa je s tem mogoče povezati tudi številne druge potrebe starejših; te so namreč lahko med sabo tesno prepletene. Prav tako je pomembno spoznanje, da je »isto potrebo treba zadovoljevati v različnih okoljih« (Findeisen idr., 2012: 51, 69). Ne zadostujejo torej pogovori o likovni umetnosti v študijskih krožkih na univerzi za tretje življenjsko obdobje - tudi umetnostni muzeji morajo starejšim ponuditi ustrezne možnosti za učenje.

Učenje v muzeju temelji na izkušnji in prav v tem je vzgojna moč muzeja, meni ena najvidnejših teoretičark na tem področju: »Učenje $\mathrm{v}$ muzejih nastaja na podlagi njihovih zbirk, pri čemer vsebina naučenega ni omejena na znanstvene discipline, ki jim te zbirke pripadajo. Učenje ni vedno namerno in se lahko zgodi na nepredviden način kot stranski produkt vrste interpretacijskih procesov. Učenje $v$ muzejih je performativno, temelji na izkušnji, je prikrito in ne vedno v polnosti artikulirano. Je močno, saj razvija oziroma oblikuje identitete. V muzejih so telesa in čuti kakor tudi razum uporabljeni za zaposlovanje $\mathrm{z}$ novimi stvarmi in za njihovo raziskovanje, za poglabljanje ali izzivanje že znanega ter za uskladiščenje prikritega znanja, ki ga je mogoče priklicati v prihodnosti.« (Hooper-Greenhill, 2006: 242)

Sodobne teorije učenja v odraslosti poudarjajo izkušnjo kot element učenja, kar vključujeta $\mathrm{v}$ 
svoje razmišljanje tudi Hergenhahn in Olson. Gre za pojmovanje učenja, pri katerem so razmeroma trajne spremembe $\mathrm{v}$ posameznikovem vedenju, znanju ali osebnosti posledica individualnih izkušenj, te spremembe pa se dogajajo ob interakciji med človekom in njegovim okoljem; izkušnja je prvi pogoj učenja (Hergenhahn, Olson, 2001: 1-11).

Pri sodobni likovni umetnosti je ta izkušnja izrazito participatorna, kot pišejo njeni teoretiki; gledalec oziroma obiskovalec praktično sodeluje pri nastajanju umetnine in oblikovanju njenega končnega pomena. (Slednje sicer velja za vso likovno umetnost.) Umetnostna zgodovinarka M. Kemperl v članku o sodobni umetnosti in državljanski vzgoji avtorica sicer piše o osnovnošolski pedagogiki - participatorno naravo sodobne likovne umetnosti poveže $\mathrm{z}$ didaktično metodo igre vlog (2013: 103). Ker se ta metoda uporablja tudi v izobraževanju odraslih, saj se »poudarja dimenzija igre, iskanja, raziskovanja« (Ličen, 2006: 115, 121, 124), so sodobne likovne prakse (npr. instalacije) seveda zanimive tudi za učenje starejših. Pri doživljanju sodobne likovne umetnosti gre namreč za neke vrste »simbolna dejanja«, ki jih v neposrednem stiku z umetnino izvrši njen udeleženec. ${ }^{2}$ Umetniško delo torej dovrši. Ta dejanja temeljijo na igri, katere bistvena značilnost - v primerjavi s klasično pojmovano metodo igre vlog - je, da je »avtentična «. Poleg tega je po mnenju avtorice bolj »prepričljiva in učinkovita« od gledanja podobe (Kemperl, 2013: 103).

Upoštevaje zgoraj izbrana teoretična izhodišča, me v tej raziskavi zanima, kakšen odnos imajo starejši odrasli do sodobne likovne umetnosti in kakšen je potencial ustrezno zasnovanega izobraževanja pri razvoju oziroma oblikovanju tega odnosa - torej pri učenju.

\section{METODOLOGIJA}

Raziskovalna metodologija je kvalitativna študija primera razstave sodobne umetnosti v Muzeju sodobne umetnosti, pospremljene z bralnim seminarjem, kjer je bila uporabljena tehnika fokusne skupine.

Muzej sodobne umetnosti, odprt leta 2011, se nahaja na Metelkovi v Ljubljani (od tod kratica MSUM). Ne gre za novo in posebno institucijo, temveč za novo stavbo in dejavnost, ki jo utemeljuje ustanovitveni akt Moderne galerije iz leta 1947. Muzej ima stalno razstavo, poleg tega prireja občasne razstave sodobne likovne umetnosti. Med 19. marcem in 6. majem 2013 je tam razstavljal Jože Barši (roj. 1955), slovenski umetnik srednje generacije, profesor na Akademiji za likovno umetnost in oblikovanje v Ljubljani. ${ }^{3}$ Barši je ob pregledni razstavi svojih del vodil bralni seminar, s katerim je želel sodobno likovno umetnost približati širšemu občinstvu.

Seminar je temeljil na ideji »obiskovalca kot mislečega gledalca«, kakršnega sodobna umetnost praviloma zahteva oziroma, kot se je izrazil sam umetnik, nanj »računa « (Železnik, 2013: 470). Seminar naj bi vključeval »tiste, ki se še ukvarjajo ali se še bodo ukvarjali z umetnostjo (umetnostne zgodovinarje), pa tudi tiste, ki bi iz prostočasnega zanimanja želeli narediti nekaj več oziroma se v prostem času poglabljati $\mathrm{v}$ Z umetnostjo povezana vprašanja« (prav tam). Seminar se je začel nekaj mesecev pred razstavo s pogovori o sodobni likovni umetnosti. Nadaljeval se je po njeni otvoritvi z vodenimi ogledi razstave, ki so jih izvajali »usposobljeni« udeleženci seminarja pa tudi sam umetnik.

Vabilo na seminar je dobila tudi Univerza za tretje življenjsko obdobje v Ljubljani. Prejeli so ga številni študijski krožki oziroma 
vanje vpisani slušatelji, ${ }^{4}$ a se nanj ni odzval niti eden. Bralni seminar, izvorno mišljen kot medgeneracijski, je po besedah kustosinje tako potekal le ob sodelovanju mlajših odraslih, študentov različnih študijskih smeri, največ pa umetnostne zgodovine (prav tam). Po odprtju razstave sta se dva študijska krožka za umetnostno zgodovino pod mojim mentorstvom načrtno odpravila v muzej. Pred obiskom in po ogledu razstave, ki ga je vodil Barši, sem s slušatelji opravila pogovor, ki je bil strukturiran po načelih metode fokusne skupine. Spraševala sem jih po tem, kakšne izkušnje imajo s sodobno likovno umetnostjo in muzeji (tudi konkretno MSUM), iz česar se je izluščil njihov odnos do tega. Delno sem torej preverjala njihov kulturni kapital in željo po učenju.

Za kvalitativno metodologijo sem se odločila, ker sem se želela približati pogledu posameznika. Nekaterih družbenih pojavov namreč ne moremo izmeriti oziroma eksperimentalno proučiti kot »količine, vrednosti, intenzivnosti in pogostnosti « (Denzin in Lincoln, 2011: 8), ampak je treba pojave razumeti, to pa je mogoče le s celovitim in neposrednim raziskovalnim pristopom.

Oba pogovora sta bila v izhodišču zastavljena skupinsko: v dveh študijskih krožkih, ki štejeta vsak po 20 do 25 članov (odvisno od prisotnosti, ki je prostovoljna), sem torej izvedla en pogovor pred ogledom razstave in enega po njem. Slušatelji so se v pogovor vključili prostovoljno. V prvem je v obeh skupinah sodelovalo v povprečju po osem ljudi; med njimi so bili tudi moški. Drugi pogovor pa je zajel skupno 13 posameznikov, ki so bili vmes v muzeju; tokrat so sodelovale samo ženske. ${ }^{5}$

Raznolika in karseda osebna mnenja udeležencev sem pridobila s čim manj strukturiranim oziroma čim bolj odprtim pogovorom (prim. Silverman, 2010: 110). Ker se v pogovor niso vključili čisto vsi, sem med preostalimi zlahka spodbujala interakcijo. Tega ni bilo težko izpeljati tudi zato, ker so se udeleženci med sabo predhodno že dobro poznali. Tu se je pogovor metodološko približal fokusni skupini, katere bistvena značilnost je, da posameznik v skupini pove več, kot če bi bil sam; mnenju drugega lahko nasprotuje ali se z njim strinja (prim. Macnaghten, Myers, 2004: 65). Kljub temu v izvorno veliki skupini vidim omejitev raziskave. To pomeni, da ugotovitve temeljijo na podatkih, pridobljenih od sodelujočih udeležencev, vprašanje pa ostaja, kaj si o sodobni umetnosti mislijo preostali tisti torej, ki se v pogovor niso vključili.

Teme iz prvega pogovora sem si zapisala, drugi pogovor pa mi je delno uspelo posneti z diktafonom, kar mi je omogočalo natančnejšo transkripcijo povedanega. Pridobljene podatke sem kvalitativno analizirala z oblikovanjem in izbiranjem kodov in kategorij.

$\mathrm{Na}$ podlagi opisanega raziskovalnega postopka je mogoče ugotovitve raziskave znanstveno posplošiti. Seveda pri posploševanju ne gre za logiko statističnega sklepanja, ampak za logiko pojasnjevanja narave procesa (Gobo, 2004). Kot pravi R. Mason (1996: 6), naj bi kvalitativna raziskava "prinesla razlage družbenega, ki so na neki način posplošljive oziroma imajo širši odmev.«

Preden preidem na rezultate, še beseda o Baršijevem konceptu vodenega ogleda, ki je nujen sestavni del opisa proučevanega primera. Njegov namen je bil »v prvi vrsti navdušiti še ne povsem formirane poznavalce umetnosti in jim kot nekakšno motnjo vnesti tisto zasnovo problema, ki bi povzročila, da bi o (sodobni) umetnosti morda začeli razmišljati drugače « (Železnik, 2013: 471). Po tem lahko sklepamo, da gre za namerno motiviranje 
udeležencev in spodbujanje refleksivnega odnosa. V tej smeri je bil zastavljen tudi ogled; kot je značilno za muzej, smo se premikali od prostora do prostora, umetnik pa je predstavljal posamezna umetniška dela in razlagal njihov koncept. Kljub majhni skupini - vodenega ogleda se je, kot že rečeno, udeležilo 13 žensk - interakcije z obiskovalkami niti ni bilo, umetnik pa je pri njih predvideval nekoliko večji kulturni kapital, kot so ga udeleženke pokazale skozi pogovor v raziskavi. Če bi ta ogled razstave presojali kot izobraževalni dogodek, bi lahko rekli, da se je Barši izkazal, če uporabim besede N. Ličen (2006: 129), za »strokovnjaka za vsebino izobraževanja, manj pa za načrtovanje in izpeljavo procesa izobraŽevanja«. Živo vodstvo pomeni neposreden stik interpreta s publiko, s tem pa direkten naslon na obiskovalčevo predznanje in sprotno prilagajanje vsebin in metod. Baršijev vodeni ogled bi zahteval posebno analizo.

\section{PREDSTAVITEV IN ANALIZA REZULTATOV}

Rezultate predstavljam in analiziram $\mathrm{v}$ treh sklopih. To so ključne kategorije, ki so ilustrirane $\mathrm{z}$ izbranimi navedki. Ker gre za osebna mnenja udeležencev, so nekatere teme izražene bolj eksplicitno, druge manj. V analizi zato navedke ustrezno teoretsko podprem. Namen tako zasnovane predstavitve in analize rezultatov je prikazati odnos starejših odraslih do sodobne likovne umetnosti in vlogo izobraževanja pri razvoju tega odnosa.

\section{Izkušnje in mnenja starejših odraslih o sodobni likovni umetnosti}

Starejši odrasli večinoma nimajo izkušenj s sodobno likovno umetnostjo in jim ta ni znana. Kot raziskovalka se zavedam omejenosti skupine, ki je bila vključena $\mathrm{v}$ raziskavo, a hkrati je pomemben podatek, da so to bile študentke (in v prvi fokusni skupini tudi študenti) študijskega krožka umetnostne zgodovine Univerze za tretje življenjsko obdobje, kar pomeni, da so bile motivirane za spoznavanje umetnosti.

$\mathrm{Na}$ izhodiščno vprašanje, ali so že obiskali MSUM, sta le dve udeleženki odgovorili pritrdilno, a se je izkazalo, da si zbirke sploh nista ogledali. V muzeju sta bili z vnuki; ena je bila z otrokom na »pedagoški dejavnosti na ploščadi«, druga je z otrokom samo zaokrožila po pritličju stavbe, nato je otrok »silil ven«. Pred našim obiskom torej starejši MSUM niso poznali. Prav tako niso znali navesti kakršnegakoli drugega primera, ko bi se srečali s sodobno likovno umetnostjo - bodisi v galeriji bodisi na drugih odprtih ali zaprtih javnih površinah, kjer se sodobna likovna umetnost razstavlja oziroma dogaja. Sodobna likovna umetnost je namreč naravnana k nagovarjanju širšega občinstva, zato jo najdemo na ulicah, po katerih hodimo, v trgovinah, ki jih obiskujemo, in drugje. Vprašanje pa je, ali jo opazimo.

Iz tega nepoznavanja izhajajo tudi njihova mnenja o sodobni umetnosti. Dejali so, da nad sodobno umetnostjo »niso navdušeni«, nad njo »so razočarani«, zdi se jim »dolgočasna«, en udeleženec je dejal, da je »provokativna«. Sodobne umetnosti ne razumejo, kar kažejo njihove izjave, kot je naslednja:

»Hočem nekaj doživeti in razumeti, moja sposobnost razumevanja pri sodobni umetnosti ne seže tako daleč.»

Večkrat so poudarili, da umetnost $\gg$ morajo razumeti«, da jo morajo tudi na »čustveni ravni doživljati«, sodobna umetnost pa da jim »nič ne predstavlja«, »nič ne pove«, zdi se jim »premalo vsebine $\ll$.

»Čudna je ta sodobna umetnost, nimaš kaj dosti gledati.« 
Umetnina mora »nuditi užitek«, mora biti »lepa«, njim pa »inštalacije« tega ne dajejo. Izrazili so dvom, da je to sploh umetnost, na primer: »Sto škatel na kupu in to je umetnost?«

Na koncept razumevanja je mogoče pogledati z dveh strani. Na eni strani gre za gledanje umetnine kot proces: umetnino je treba najprej poznati in razumeti, da se lahko nanjo čustveno odzoveš in da te zanima. Razumevanje je torej prvi pogoj našega odziva na umetnino, na kar so pokazale že dosedanje eksperimentalne študije o obiskovalčevi sposobnosti tvorjenja pomena umetnine - njegovem umevanju (npr. Lachapelle, 1999; Bergmann Drewe, 1999; Hooper-Greenhill idr., 2001; Van Moer, 2007). Na drugi strani gre za umetnostni muzej kot prostor estetskega doživljanja - prostor razumevanja umetnosti. Po Gadamerju (2001: 11) razumevanje pomeni »pridobivanje uvidov in spoznavanje resnic «. Muzej kot »kulturna ustanova par excellence« (Tavčar, 2009: 84) tako nastopa kot prostor izobraževanja.

\section{Pri učenju v mu- zeju se je kot po- membna izkazala interpretacija, razlaga.}

nazadnje tudi to, da mora biti »lepa«, je razvidno, kako starejši, ki so bili sogovorniki v moji raziskavi, opredeljujejo likovno umetnost, svoj odnos do nje. Konkretno te navedbe apelirajo na teorijo o mimetični oziroma predstavljajoči umetnosti, ki je značilna za starejšo umetnost. (Očitno pa niso seznanjeni s figurativno, materialno, konceptualno in vsebinsko/sporočilnostno naravo sodobne likovne umetnosti.) Znanje o likovni umetnosti seveda vključuje tudi poznavanje določenih teorij o likovni umetnosti. Teorije pa producirajo institucije, muzeji. Gre za »politična vprašanja«, pravi Whitehead (2012: xvi), kot so: »Kaj je umetnost in kaj ni? Zakaj? Čemu je umetnost namenjena in zakaj je umetnost dobra? Katera umetnost je dobra, zakaj in kdo tako pravi? Kako se lahko umetnost deli v tipe, medije in žanre? Kako naj človek uporabi umetnost in kakšna naj bo ta izkušnja oziroma te izkušnje? Kako naj oblikujemo svoje védenje o umetnosti?« Torej je v domeni institucije oziroma nekega sistema vzgoje in izobraževanja tudi to, da izoblikovane predstave o umetnosti pri ljudeh vzpostavlja, razvija (prenaša družbeno sprejeta pravila) in nato spreminja. Razstava, ki smo si jo ogledali v moji raziskavi, pa izhaja iz koncepta refleksivnega gledalca, torej gledalca, ki si aktivno oblikuje svoje doživetje in konstruira pomene. Kot lahko ugotovim iz povedanega $v$ fokusnih skupinah, je razlika med pojmovanji umetnosti, ki so se oblikovala pri starejših odraslih, in sodobno umetniško prakso velika, mogoče včasih (pre)velika, da bi slednja samodejno postala del njihovega zanimanja.

\section{Pomen učenja in izobraževanja o sodobni likovni umetnosti}

Tema, ki je v pogovorih tudi prišla do izraza, je bilo učenje in izobraževanje. Udeleženka, njeno mnenje se navezuje na izhodiščno vprašanje o tem, ali so že kdaj obiskali MSUM, je dejala:

»Začeti je treba skupinsko, potem se pa navadiš. «

Nekateri drugi so - v pogovoru pred obiskom muzeja - poudarili pomen razlage: če bi jim to umetnost nekdo razložil, bi začeli »drugače gledati«. Po obisku muzeja, kjer so dejansko bili deležni razlage, se je pomen interpretacije potrdil, na primer:

»Ko je povedal, si drugače gledal.« 
Kljub temu vseh umetnik ni povsem in takoj prepričal, so pa izkazali pripravljenost za učenje: »Mislim, da se moramo tudi naučiti malo drugače misliti. Razmišljati ne znamo prav.« Razlaga širi znanje, poglablja razumevanje: »Če ti eden prav predstavi umetnost, jo potem drugače razumeš. Jaz se spomnim, ko smo mi prišli pred leti v Kostanjevico, tisti samostan, in notri je en zelo moderen slikar. In smo bile kar malo razočarane. Samo potem nas je pa Kožuhova - ona ima pa rada moderno slikarstvo - postavila in rekla: ja, takole, veste, zdaj tole to pomeni, to ono, tretje, četrto ... Ko smo šle ven, smo čisto drugače razmišljale.«

Ena udeleženka je učenje opisala kot boj (sledi odlomek):

Raziskovalka: Kako vam je bilo všeč?

Udeleženka 1: V redu.

Udeleženka 2: Jaz moram predelat.

Udeleženka 1: Všeč nama je bilo, da ... da ... Udeleženka 2: ... da dobim vso to filozofijo $\mathrm{v}$ sebe.

Udeleženka 1: Jaz moram reči, da, recimo, ne, kar se mene tiče, lahko rečem, da se mi je pojavilo na momente en revolt, malo. Tako kakor, češ: »Saj to vsi vemo, kaj je to kaj takega.«

Udeleženka 2: Da je to ponavljanje.

Udeleženka 1: Ne tako, ampak tudi tako ... Raziskovalka: ... da niste hoteli sprejeti?

Udeleženka 1: Ja, jaz sem se borila, da bi. (smeh) $\mathrm{Bi}, \mathrm{z}$ veseljem. /.../ Ne morem reči, da sem navdušena, »uau, to je pa ...«, nekako se mi je zdelo, da... /.../ On nedvomno ima nek potencial, ko je nekaj v njem, kar mora iti ven. Zdaj, očitno se to nekoga dotakne, ker če ne, ne bi okoli hodil. Mene ni prepričal.

Raziskovalka: Ne.

Udeleženka 1: Ne. Ampak bi pa še šla, ker mogoče me pa enkrat bo, seveda! (smeh) Ja, ja! To ni zdaj rečeno, da odklanjam.
Spreminjanje mnenj, stališč, prepričanj, skratka odnosa starejših do sodobne likovne umetnosti (in likovne umetnosti nasploh), je dolgotrajen proces. Zlasti ti podatki pa kažejo na to, da pri izobraževanju starejših ne gre samo za zadovoljevanje že ozaveščenih potreb, ampak tudi za »razvijanje novih interesov za izobraževanje « (Ličen, 2006: 102). Dejstvo je, da se sprva prav nihče ni odločil za obisk MSUM in da tega muzeja (ter drugih lokacij sodobnih likovnih praks) tudi sicer ne obiskujejo. Potrebna je bila določena motivacija, da je potem prišlo do konkretnega učenja ob avtentičnih umetninah.

Pri učenju v muzeju se je kot pomembna izkazala interpretacija, razlaga. Ta obiskovalcu daje okvir za razumevanje razstavljenih umetniških del, zato jo uvrščamo med specifične muzejske poučevalne metode. Whitehead pravi, da je muzejska interpretacija »didaktični projekt« (2012: xii). Dejstvo, da se razumevanje likovne umetnosti razlikuje od obiskovalca do obiskovalca, naj bi bistveno usmerjalo način predstavitve in interpretacije umetnin $v$ muzejih. Interpretacija naj bi bila zasnovana tako, da umetniški predmet približa tudi manj »kompetentnim « obiskovalcem (prim. Bourdieu, Darbel, 1969/1991), ki imajo drugačno zmožnost vživljanja v likovna dela kot poznavalci likovne umetnosti in ki si pri tem pogosto pomagajo $\mathrm{z}$ informacijami ob eksponatih (gl. npr. Lachapelle, 1999; Hooper-Greenhill idr., 2001).

\section{Nov kulturni kapital}

Zadnja kategorija se nanaša na novo znanje, ki so ga udeleženci pridobili v muzeju. Poudariti je treba, da so nova spoznanja težko besedno artikulirali, saj ne poznajo ustreznega izrazoslovja. Poleg tega so lahko izrazili samo tisto, kar so zaznali, to pa je bilo odvisno od njihove zmožnosti zaznavanja in razumevanja. Ena udeleženka je denimo opisala 
enega od eksponatov, ki ga je videla (gre za zelo dolg navedek). Ker je pogovor potekal v večji skupini, sestavljeni iz tistih, ki so sodelovali pri ogledu, in tistih, ki niso, je šlo v tem primeru za predstavitev pridobljenega znanja drugim - tistim, ki niso sodelovali. (Če sem zgoraj $\mathrm{v}$ tako zasnovani skupini videla omejitev, tu zdaj vidim metodološko prednost.) Druga udeleženka je spoznala nekaj novega o umetnosti:

»Mislim, določene take razlike gledanja na eno umetnost, ko še nisem nikdar slišala. /.../ Meni se je zdelo super, no. Veliko stvari sem se ... mislim, mogoče drugače lahko gledaš za določene inštalacije ...«

Še en primer:

Raziskovalka: Kaj ste pa novega spoznale danes?

Udeleženki 3 in 4: (tišina)

Raziskovalka: Se vam zdi, da ste kaj novega slišale, kaj novega spoznale?

Udeleženka 3: Jožeta Baršija. (smeh) Ne, am, kaj je novega ...

Raziskovalka: ... kaj vam je bilo posebej všeč? Udeleženka 3: Predstavitev njegova in kaj je pojem moderna umetnost. Da je to pravzaprav en zelo širok pojem. In ni nujno, da je nekaj napacano gor.

Raziskovalka: Vi ste spoznali kaj novega danes?

Udeleženka 4: Neverjetne stvari, kako ta človek razmišlja, kako to povezuje ... neverjeten je, no. Saj ne moreš verjeti, kaj se ... kako si omejen tam v mojih Guncljah, če ne bi šel nikamor, a ne? Ne vem. Jaz rada spremljam stvari.

Ta kategorija je tesno povezana s predhodno: pomen učenja in izobraževanja. Jasno je razvidna korelacija med vodenim ogledom oziroma umetnikovo interpretacijo - to, da je Barši obiskovalkam umetniška dela razložil
- in pridobljenim novim znanjem. To je mogoče direktno nasloniti na Bourdieujev koncept kompetence: človek do estetskega užitka pride $» \mathrm{Z}$ navado in vajo « (Bourdieu, Darbel, 1969/1991: 109).

\section{SKLEP}

Čeprav je zgodovina likovne umetnosti vsaj od 90. let 20. stoletja ena najbolj obiskanih študijskih vsebin na Univerzi za tretje življenjsko obdobje, je po neodzivnosti slušateljev na vabilo Muzeja sodobne umetnosti, da se pridružijo medgeneracijskemu bralnemu seminarju, ki ga je ob razstavi svojih del vodil umetnik Jože Barši, mogoče sklepati, da se starejši slušatelji s sodobno likovno umetnostjo - umetnostjo, ki nastaja tukaj in zdaj - v okviru študijskih krožkov umetnostne zgodovine srečujejo zelo redko ali celo nikoli. K tej težnji najbrž pripomore več stvari, med katerimi je verjetno dejstvo, da pri nas izobraževalne vsebine na področju likovne umetnosti ne temeljijo na razvijanju sodobno pojmovane estetske kompetence oziroma zmožnosti, kar je mogoče pri izobraževanju starejših pripisati bolj družbenim kot individualnim razlogom (prim. Findeisen idr., 2012: 33, 38, 39).

Kvalitativna raziskava, v kateri sem proučevala mnenja starejših odraslih o sodobni likovni umetnosti pred obiskom muzeja in po ogledu razstave Baršijevih del pod vodstvom samega umetnika, je na eni strani pokazala, kakšen odnos imajo starejši odrasli do sodobne likovne umetnosti. Predvsem je ne poznajo in z njo nimajo izkušenj, zato se jim zdi nerazumljiva in jo odklanjajo. $\mathrm{Na}$ drugi strani je raziskava pokazala na potencial učenja in izobraževanja. Korelacija med izraženimi potrebami po učenju ter obiskom razstave oziroma učno izkušnjo v muzeju na 
eni strani in pridobljenim kulturnim kapitalom na drugi strani, ki bi jo sicer veljalo potrditi z novimi empiričnimi podatki (še posebej na ravni novega kulturnega kapitala), predvsem nakazuje pomen ustrezno zasnovanega izobraževanja. Sklepam, da je pri izobraževanju starejših, ko gre za sodobno likovno umetnost, v prvi fazi treba razvijati nove možnosti za učenje in spoznavanje sodobne likovne umetnosti, ki se bodo najprej približale starejšim odraslim in pri njih spodbudile zanimanje ter nato razvijale potrebe po soočanju s sodobno likovno umetnostjo. Če bi z izobraževanjem zgolj sledili že razvitim potrebam (osebnim zanimanjem) starejših odraslih, jih v neposreden stik s sodobno likovno umetnino ne bi privabili, kar je potrdila tudi študija primera v MSUM.

S tega vidika rezultati raziskave in pričujoči prispevek uvajajo nov in drugačen premislek o izobraževanju starejših odraslih na področju sodobne likovne umetnosti, kar lahko pogojno razširimo tudi na druga področja izobraževanja starejših. Predvsem gre za vprašanje, kaj mora starejši človek znati za izboljšanje svojega življenja in za izboljšanje sedanje družbe - družbe v krizi - ter kakšne možnosti in izzive za to ponuja sodobna likovna umetnost, za katero je značilna višja stopnja družbene odgovornosti in kritičnosti.

\section{LITERATURA}

Bela knjiga o vzgoji in izobraževanju v Republiki Sloveniji (2011). Ljubljana: Zavod RS za šolstvo.

Bergmann Drewe, S. (1999). The Rational Underpinning of Aesthetic Experience: Implications for Art Education. Canadian Review of Art Education, 26, 1: 22-33.

Bourdieu, P. (1979/2010). Distinction: A Social Critique of the Judgement of Taste. London, New York: Routledge.
Bourdieu, P. (1993). The Field of Cultural Production: Essays on Art and Literature. New York: Columbia University Press.

Bourdieu, P.; Darbel, A. (1969/1991). The Love of Art: European Art Museums and their Public. Cambridge: Polity Press.

Carroll, N. (2003). Aesthetics and the Educative Powers of Art. V: Curren, R. (ur.). A Companion to the Philosophy of Education. Oxford.

Čelebič, T. idr. (2011). Izobraževanje odraslih v Sloveniji - stanje in izzivi. Ljubljana: Pedagoški inštitut.

Denzin, N. K.; Lincoln, Y. S. (2011). Introduction: Disciplining the Practice of Qualitative Research. V: Denzin, N. K.; Lincoln, Y. S. (ur.). The Sage Handbook of Qualitative Research. London, Thousand Oaks, New Delhi, Singapore.

Dufresne-Tassé, C.; Sauve, M.; Weltzl-Fairchild, A.; Banna, N.; Lepage, Y.; Dassa, C. (1998). Pour des expositions muséales plus éducatives, accéder 1 expérience du visiteur adulte. Développement $\mathrm{d}$ une approche. Canadian Journal of Education, 23, 3: 302-315.

Émond, A. M. (2010). Positive Responses of Adult Visitors to Art in a Museum Context. V: Costantino, T.; White, B. (ur.). Essays on Aesthetic Education for the 21 st Century. Rotterdam, Boston.

Findeisen, D.; Krajnc, A.; Ličen, N.; Ivanuš Grmek, M.; Kunaver, J. (2012). Posebnosti izobraževanja starejših. Ljubljana: Društvo za izobraževanje za tretje življenjsko obdobje. Dostopno na: http:// www.slovenska-univerza3.si/docs/eMonografija_Posebnosti_izobrazevanja_starejsih.pdf. (18. 7 . 2013).

Gadamer, H. G. (2001). Resnica in metoda. Ljubljana: Literarno-umetniško društvo Literatura.

Gobo, G. (2004). Sampling, Representativeness and Generalizability. V: Seale, C.; Gobo, G.; Gubrium, J. F.; Silverman, D. (ur.). Qualitative Research Practice. London, Thousand Oaks, New Delhi.

Hergenhahn, B. R.; Olson, M. H. (2001). An Introduction to Theories of Learning. Eaglewood Cliffs (NJ): Prentice-Hall. 
Hooper-Greenhill, E. (2006). The Power of Museum Pedagogy. V: Genoways, H. (ur.). Museum Philosophy for the Twenty-First Century. Lanham.

Hooper-Greenhill, E.; Moussouri, T.; Hawthorne, E.; Riley, R. (2001). Making Meaning in Art Museums 1: Visitors' Interpretive Strategies at Wolverhampton Art Gallery. Leicester: Research Centre for Museums and Galleries (RCMG), University of Leicester.

Hooper-Greenhill, E.; Moussouri, T. (2001). Making Meaning in Art Museums 2: Visitors' Interpretive Strategies at Nottingham Castle Museum and Art Gallery. Leicester: Research Centre for Museums and Galleries (RCMG), University of Leicester.

Kemperl, M. (2013). Contemporary Art and Citizenship Education: The Possibilities of Cross-Curricular Links on the Level of Content. CEPS Journal, 3, 1: 97-122.

Lachapelle, R. (1999). Comparing the Aesthetic Responses of Expert and Non-Expert Viewers. Canadian Review of Art Education, 26, 1: 6-21.

Ličen, N. (2006). Uvod v izobraževanje starejših: izobraževanje starejših med moderno in postmoderno. Ljubljana: Filozofska fakulteta, Oddelek za pedagogiko in andragogiko.

Macnaghten, P.; Myers, G. (2004). Focus Groups. V: Seale, C.; Gobo, G.; Gubrium, J. F.; Silverman, D. (ur.). Qualitative Research Practice. London, Thousand Oaks, New Delhi.

Mason, J. (1996). Qualitative Researching. London, Thousand Oaks, New Delhi: Sage Publications. Newman, A.; Goulding, A.; Whitehead, C. (2012). The Consumption of Contemporary Visual Art: Identity Formation in Late Adulthood. Cultural Trends, 21, 1: 29-45.

Peček Čuk, M.; Lesar. I. (2009). Moč vzgoje: sodobna vprašanja teorije vzgoje. Ljubljana: Tehniška založba Slovenije.

Piškur, B. (2013). Barši. V: Soban, T. (ur.), Jože Barši. Ljubljana.

Silverman, D. (2010). Interpreting Qualitative Data: Methods for Analyzing Talk, Text and Interaction. London, Thousand Oaks, New Delhi: Sage Publications.
Šterman, I. (2006). Umetnostna zgodovina v tretjem življenjskem obdobju: ikonografski pristop kot pot do umevanja (magistrsko delo). Ljubljana: Filozofska fakulteta, Oddelek za umetnostno zgodovino.

Tavčar, L. (2009). Homo spectator. Uvod v muzejsko pedagogiko. Ljubljana: Pedagoški inštitut.

Van Moer, E. (2007). Talking about Contemporary Art: The Formation of Preconceptions During a Museum Visit. The International Journal of the Arts in Society, 1, 3: 1-7.

Whitehead C. (2012). Interpreting Art in Museums and Galleries. London, New York: Routledge.

Železnik, A. (2013). Učitelj. V: Soban, T. (ur.). Jože Barši. Ljubljana.

1. Iz magistrske naloge I. Šterman (2006), doslej edinega znanstvenega dela na tem področju pri nas (delo ni objavljeno), kjer avtorica predstavlja lastno prakso mentorice za umetnostno zgodovino na Univerzi za tretje življenjsko obdobje, je posredno razvidno, da izobraževalni proces ni naravnan k razvijanju zmožnosti za doživljanje in razumevanje umetnosti (t. i. estetske kompetence), ki edina omogoča razvijanje zanimanja za nove zvrsti umetnosti in njihovo razumevanje. (Več o konceptu kompetence $\mathrm{v}$ teoretičnem okviru.)

2. Avtorica za primer vzame instalacijo v Čilu rojenega in na Danskem živečega umetnika Marca Evaristtija (roj. 1963) z naslovom »Helena«. Umetnik je deset kuhinjskih mešalnikov napolnil z vodo in v vsakega dal po eno živo zlato ribico; obiskovalec je lahko ribico zmel ali ne (razstavljeno leta 2000 v Koldingu in leta 2006 v Dornbirnu). »Preden smo se lotili tega dejanja, smo morali temeljito razmisliti, ali bomo to storili ali ne in zakaj - razmišljali smo o našem ambivalentnem odnosu do živali.« (Kemperl, 2013: 103.)

3. Barši s posebnimi kiparskimi in arhitekturnimi koncepti (npr. Javno stranišče, 1999) raziskuje in posega $v$ fizični in družbeni prostor, zanimata ga tudi politična filozofija in umetnost, zato pogosto spoznavamo le tekste, misli, ideje, ki niso nujno materializirani v klasični umetniški formi, kot sta slika ali kip. Od obiskovalca predvsem zahteva, da misli 
»konceptualno« (prim. Piškur, 2013). Več o razstavi: http://www.mg-lj.si/node/1041

4. Če pogledamo statistiko samo za umetnostno zgodovino: v študijskem letu 2012/2013 je na univerzi delovalo 38 študijskih krožkov, v katere je bilo vpisanih 944 starejših oseb (vir: Univerza za tretje življenjsko obdobje).

5. Čeprav so v obeh študijskih krožkih tudi moški - v enem dva, v drugem trije, kar v povprečju pomeni slabih 10 odstotkov - se za obisk MSUM ni odločil nihče od njih. Razlogov nisem preverjala - niti pri njih niti pri drugih. 